\title{
Bolivina lata sp. nov., a new foraminiferal species in the family Bolivinitidae from Niger Delta, Nigeria
}

\author{
Enam Okon Obiosio \\ Department of Geology, Ahmadu Bello University, Zaria, Nigeria \\ Email: eoobiosio@abu.edu.ng
}

\begin{abstract}
A new benthonic foraminifera, Bolivina lata sp. nov. is described from the Niger delta basin of Nigeria. This foraminiferal species occurs abundantly in the Oligocene of the basin.
\end{abstract}

\section{Introduction}

The Niger Delta basin is situated in the Gulf of Guinea, into which it progrades and lies between latitude $4^{\circ}-6^{\circ} \mathrm{N}$ and longitude $3^{\circ}-9^{\circ} \mathrm{E}$ (Fig. 1 ).

Biostratigraphic studies involving the use of Bolivina for biostratigraphy have been presented by Petters (1982) and regional phylogenetic analysis of Bolivinitidae of basins within the Gulf of Guinea, including the Niger delta (Brun et al., 1984). Because studies were conducted at regional scale, the documentation of the Bolivinitidae in the basin remains rather unsatisfactory. Not much attention has been paid on the morphology of the bolivinids of the basin.

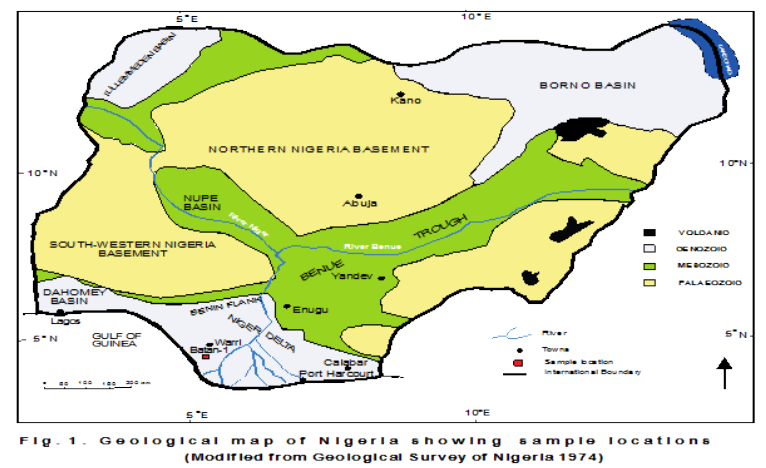

Fig. 1: Geological map of Nigeria showing sample locations (modified after Geological Survey of Nigeria, 1974) 
The objective of this paper is to describe a new Bolivina species, Bolivina lata sp. nov. and present the scanning electron micrograph of its form.

Scanning electron microscope study for this paper was carried out at the Insitut fur Geowissenschaften, Christian- Albrechts - Universitat Zu kiel, Germany. Holotype representing the species described was deposited in the same University.

\section{Discussion}

The distribution of Bolivina lata sp. nov. ranges from intervals $3123-3280 \mathrm{~m}$ of the studied well (Batan-1). This interval represents a general Oligocene age on the basis of planktonic foraminifera (Petters, 1983). The Oligocene age is corroborated by the last occurrence of Bolivina ihuoensis Reyment, in this study, which agrees with Brun et al. (1984).

\section{Taxonomic Description}

The classification used in this work is that of Loeblich and Tappan (1987). The identification of the Bolivina species is based entirely on Cushman (1911) definition of the genus.

Order FORAMINIFERIDA Eichwald, 1830

Superfamily BULIMINACEAE Jones, 1895

Family BOLIVINITIDAE Cushman, 1927

Genus Bolivina d'Orbigny, 1839

Type species: Bolivina plicata d’Orbigny, 1839

Bolivina lata sp. nov.

Fig. 2 (1-3)

Derivatio nominis: The species name is derived from a Latin qualifier "latus" (broad), with reference to the broad last chamber pair.

\author{
Holotype: \\ Type Locality: \\ Type horizon: \\ Diagnosis:
}

\author{
ABUGM 0705; Figs. 2 (1 - 3) \\ Batan-1 well, Western Niger Delta, Nigeria \\ Oligocene strata of Batan-1 well, from 3123 - 3280 m \\ Broad, greater flare of the last pair of chambers. Distinctive 5 pairs of \\ chambers.
}

Description: Test small, biserial, stout, somewhat inflated; periphery very rounded, 5 chambers in each row, first 3 chambers low, last 2 high; sutures distinct depressed, limbate, oblique slanting at almost $45^{\circ}$; ornamented with longitudinal costae originating from the proloculus, about 1 or 2 of the costate are anastomosing; costae become obsolescent at the base of the last pair of chambers, with 2 faintly continuing into the last pair; coarsely perforated, pores are sunken and nearly equally spaced; periphery at last pair of chambers surrounded; a keel terminates at the base of the last pair of chambers; aperture longitudinal slit though not clearly visible on apertural face but the relict is slightly visible; the specimens generally are well preserved. 


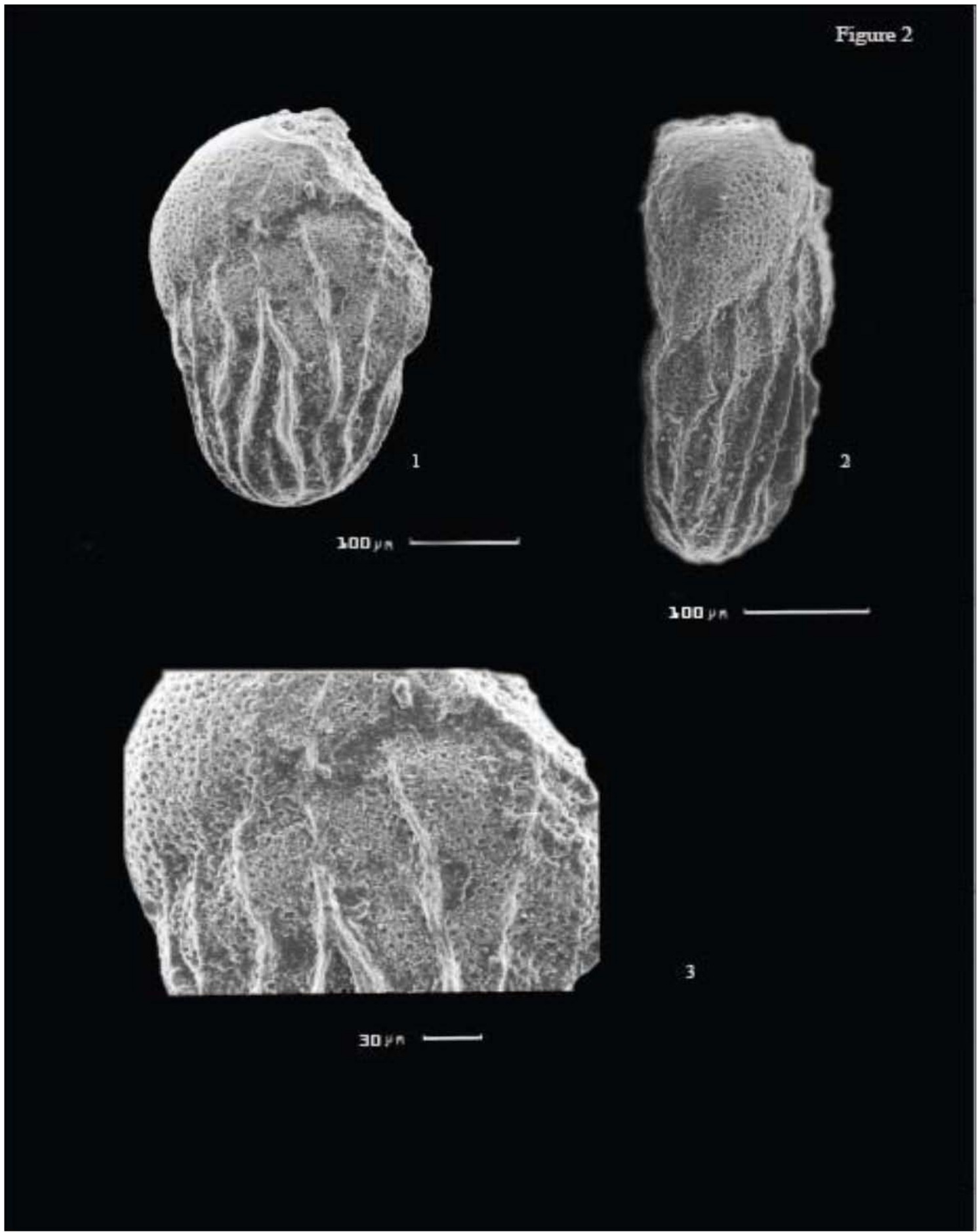

Fig. 2: Scanning electron micrograph of Bolivina lata sp. nov. (1) Side view; (2) Peripheral view; (3) enlarged part of 2.1. 
Dimension: Holotype

$\begin{array}{ll}\text { Length } & 0.25 \mathrm{~mm} \\ \text { Width } & 0.16 \mathrm{~mm}\end{array}$

Paratype:

$\begin{array}{lccc}\text { SPECIMEN NUMBER } & \text { WIDTH }(\mathrm{W}) \mathrm{mm} & \text { LENGTH }(\mathrm{L}) \mathrm{mm} & \text { L/W } \\ \text { A.0744/1 } & 0.16 & 0.25 & 1.56 \\ \text { A.0744/2 } & 0.17 & 0.25 & 1.47 \\ \text { A.0744/3 } & 0.16 & 0.23 & 1.44 \\ \text { A.0744/4 } & 0.19 & 0.26 & 1.37 \\ \text { A.0744/5 } & 0.20 & 0.28 & 1.40 \\ \text { A.0744/6 } & 0.21 & 0.31 & 1.47 \\ \text { A.0744/7 } & 0.23 & 0.35 & 1.52 \\ \text { A.0744/8 } & 0.23 & 0.36 & 1.56\end{array}$

Remarks: Different from Bolivina inflata in that B.inflata Heron- Allen and Earland has a greater chamber flare compared to Bolivina lata sp. nov. Bolivina lata sp. nov. possesses a keel around the periphery but no carinate sutures while B.inflata possesses carinate sutures. Bolivina lata sp. nov is a phenotypically diverse species, as populations display variations in suture incision/raising, keel development.

Occurrence: Common in Oligocene of the Niger Delta from 3123 - 3280 m.

Acknowledgement: Thanks are extended to Wolfgang Kuhnt and Ann Holbourn for providing support for the use of scanning electron microscope at the University of Kiel, Germany. Ann Holbourn for useful suggestion on taxonomy. Thanks to Ute of the University of Kiel, Germany for assistance in preparing the scanning electron micrograph. This research was funded by the MacArthur Foundation and the Ahmadu Bello University. I would want to acknowledge E. A. Okosun for his contribution to this work. I am grateful to S. W. Petters and P. M. Zaborski for the invaluable support they rendered.

\section{References}

Brun, L., Chierici, M. A. and Meijer, M. (1984) Evolution and morphological variations of the principal species of Bolivinitidae in the Tertiary of the Gulf of Guinea: Geologie Mediterraneenne, Tome XI, no. 1, pp. $13-57$.

Cushman, J. A. (1911) A monograph of the foraminifera of the North Pacific Ocean. Part 2, Textularidae, United States Museum of Natural History Bulletin, v. 71(2), 108p.

Cushman, J. A. (1927) An outline of re-classification of the Foraminifera: Cushman Lab. Foram. Res. Contr., v. 3(1), 105p.

d’Orbigny, A. D. (1839) Voyage dans L'Amérique méridionale - Foraminifèrès. - Pitois Levrault et C (Paris), v.5, 86p.

Eichwald, C.E. von. (1830) Zoologia specialis. Vilnae: D.E. Eichwaldus, v. 2, 323p.

Geological Survey of Nigeria (1974) Geological map of Nigeria. Scale 1: 2,000,000. Geological Survey Division, Federal Ministry of Mines and Power, Nigeria.

Jones, T. R. (1895) A monograph of the foraminifera of the Crag, Pt. 2. Palaeont. Soc. London, pp.73 - 210.

Loeblich, A. R., Jr. and Tappan, H. (1987) Foraminifera and their Classification: Van Nostrand Reinhold Company, New York, 970 p.

Petters, S. W. (1982) Central West African Cretaceous-Tertiary benthic foraminifera and stratigraphy: Palaeontographica Abt. Av, v. 179, 104 p.

Petters, S. W. (1983) Gulf of Guinea planktonic foraminiferal biochronology and geological history of the South Atlantic. Jour. Foram. Res., v. 13, pp. 32-59. 